\title{
BENTUK PEMBERDAYAAN DAN MANFAAT 'TOURISM AND HOME ASSISTANT PROGRAM' TERHADAP PARIWISATA DI KABUPATEN BULELENG
}

\author{
I Gede Sukma Adisatria Sukadana', Ni Made Sofia Wijaya², \\ Dewa Putu Oka Prasiasa ${ }^{3}$ \\ 1,2Universitas Udayana, ${ }^{3}$ STIMI Handayani Denpasar
}

\begin{abstract}
The aim of this study is to analyze the forms of empowerment carried at Tourism and Home Assistant Program, its model of empowerment, and its advantage on tourism activity in Buleleng Regency. The problems of the study were conducted with qualitative phenomenology approach. Data of the study were analyzed by utilizing qualitative descriptive method. Data collection techniques utilized observation, documentation studies, and in-depth interviews. The results of this study shows that the forms of community development activities in Tourism and Home Assistant Program were one year tourism training and providing incidental help. Analysis of empowerment model Tourism and Home Assistant Program consisted of creating relevant curriculum, management, marketing, supervision, implementation of clear education system, recruitment systems, cooperation with the users of the graduates, and provide sustained professional development. The interpretation of the data indicates that Tourism and Home Assistant Training Program has advantage on tourism activity of Buleleng Regency such as promotion of tourism activity through social care activities.
\end{abstract}

Keywords : tourism training, empowerment, home assistant program.

\begin{abstract}
Abstrak
Artikel ini bertujuan untuk melihat bentuk, model pemberdayaan, dan manfaat Tourism and Home Assistant Program terhadap kegiatan wisata di Kabupaten Buleleng. Permasalahan yang dikaji dalam penelitian ini menggunakan pendekatan kualitatif fenomenologi dan dianalisis secara deskriptif kualitatif dengan teknik pengumpulan data berupa observasi, studi dokumentasi, dan wawancara mendalam. Hasil dari penelitian ini mengemukakan bahwa bentuk-bentuk kegiatan pemberdayaan masyarakat yang tidak mampu melalui pelatihan Tourism and
\end{abstract}


Home Assistant Program yaitu pelatihan pariwisata satu tahun, dan pemberdayaan melalui bantuan insidental. Analisis model pemberdayaan Tourism and Home Assistant Program, yaitu model pemberdayaan Tourism and Home Assistant Program dibentuk dengan cara melalui pembuatan kurikulum yang relevan, pengaturan manajemen, pemasaran, pengawasan, penggunaan sistem pelaksanaan pendidikan yang jelas, sistem perekrutan calon peserta pelatihan, kerjasama dengan pihak pemakai lulusan, dan memberikan professional development yang berkelanjutan. Manfaat dengan adanya pelatihan Tourism and Home Assistant Program terhadap kegiatan wisata di Kabupaten Buleleng yaitu promosi pariwisata Kabupaten Buleleng melalui kegiatan kepedulian sosial.

Kata kunci: pelatihan pariwisata, pemberdayaan masyarakat, home asistant program

\section{Pendahuluan}

Era globalisasi dan informasi menuntut setiap negara untuk mampu berkolaborasi dan meningkatkan kualitas diri agar tidak tertinggal dibandingkan dengan negara-negara lain. Indonesia bersama negara-negara Asia Tenggara membentuk suatu bentuk kerjasama yang terintegrasi dan dikenal dengan nama Economic ASEAN Community, dalam istilah bahasa Indonesia dikenal sebagai Masyarakat Ekonomi ASEAN (MEA). Kebijakan tentang MEA juga berpengaruh terhadap dunia pariwisata karena dengan adanya kebijakan MEA persaingan dalam penyediaan barang dan jasa di dunia pariwisata akan semakin ketat dan kompetitif. Pariwisata adalah industri yang menghasilkan banyak devisa negara sehingga pemerintah ingin meningkatkan pendapatan pada sektor pariwisata dengan melakukan berbagai upaya dalam pembangunan pariwisata.

Bali sebagai salah satu destinasi pariwisata unggulan di Indonesia, dilihat dari pertumbuhan pariwisatanya, memiliki jumlah kunjungan wisatawan dengan peningkatan yang menjanjikan. Hal tersebut didasari data Badan Pusat Statistik Provinsi Bali yang menunjukkan bahwa jumlah kunjungan wisatawan yang datang ke Bali periode 2011-2015 selalu meningkat dari tahun ke tahun. Jumlah kunjungan wisatawan yang meningkat datang ke Bali memberikan indikasi yang memperkuat fenomena bahwa Bali adalah salah satu destinasi wisata terbaik di dunia. Sebagai tujuan wisata yang terkenal, Bali diharapkan dapat memberikan peluang kerja yang memadai di bidang pariwisata. Namun kenyataannya, harapan tersebut belum sesuai dengan kenyataan. Banyak orang-orang lokal Bali yang tidak dapat bersaing mencari pekerjaan dalam sektor pariwisata dan akhirnya menjadi pengangguran. 
Salah satu daerah di Bali yang masih memiliki penduduk miskin dan pengangguran adalah Kabupaten Buleleng. Berdasarkan survei Badan Pusat Statistik Provinsi Bali tingkat kemiskinan di Buleleng tahun 2015 adalah 5,19 persen dari jumlah penduduk 625.125, tertinggi dari angka kemiskinan di Provinsi Bali sebesar 4,1 persen (kompas.com, 2015). Kabupaten Buleleng sangat memerlukan pengembangan kompetensi tenaga kerja pariwisata. Hal ini didukung oleh pendapat Kepala Dinas Tenaga Kerja Buleleng yang mengatakan bahwa tenaga kerja lokal asal Buleleng masih perlu mendapatkan pelatihan lebih intensif lagi dalam bidang pariwisata (bali. antaranews.com, 2017). Hal ini disinyalir oleh kurang terampilnya tenaga kerja lokal untuk mempromosikan potensi wisata Bali Utara, sehingga jumlah kunjungan wisatawan yang datang ke Kabupaten Buleleng tidak sebanyak jumlah kunjungan wisatawan yang ada di Bali Selatan.

Berdasarkan penelitian, kurangnya kunjungan wisatawan ke tempat wisata di Bali Utara juga berdampak pada kurangnya penyerapan tenaga kerja sehingga banyak terjadi pengangguran. Oleh sebab itu perlu upaya yang melibatkan lembaga pendidikan untuk ikut serta meningkatkan kualitas sumber daya manusia Bali Utara agar mampu bersaing mencari pekerjaan di daerah wisata di Bali maupun untuk mengembangkan wisata yang potensial di Bali Utara. Salah satu lembaga yang bergerak di bidang pendidikan pariwisata di Kabupaten Buleleng yang memberdayakan generasi muda adalah Tourism and Home Assistant Program (THAP) di bawah naungan Yayasan Aura Sukma Insani. Program pendidikan pariwisata ini diawali pada tahun 2010 dengan memulai program pariwisata pelatihan satu tahun bagi siswa yang sudah tamat SMA/SMK dan tidak mampu untuk melanjutkan pendidikan ke jenjang yang lebih tinggi. Tujuan program ini adalah memberdayakan remaja kurang mampu agar memiliki kompetensi untuk mendapatkan pekerjaan. Banyak anak-anak muda yang menyelesaikan pendidikan di SMA/SMK namun mereka sangat sulit untuk mendapatkan pekerjaan yang layak karena sedikit dari mereka yang memiliki skill tambahan. Berdasarkan fenomena inilah Tourism and Home Assistant Program ini relevan dengan kebutuhan pariwisata Bali.

Berkenaan dengan latar belakang di atas, maka perlu diadakan penelitian secara khusus dan lebih mendalam terhadap lembaga pelatihan satu tahun tersebut untuk melihat bentuk pemberdayaan, analisis model pemberdayaan, dan manfaat Tourism and Home Assistant Program terhadap kegiatan wisata di Kabupaten Buleleng.

Sehubungan dengan latar belakang permasalahan tersebut, rumusan masalah dalam penelitian iniadalahbagaimanabentukpemberdayaan Tourism and Home Assistant Program? Bagaimana analisis model pemberdayaan Tourism and Home Assistant Program? Bagaimana manfaat Tourism and Home Assistant Program terhadap kegiatan wisata di Kabupaten Buleleng? 


\section{Metode Penelitian}

Penelitian ini menggunakan model pendekatan kualitatif fenomenologi. Penelitian dilakukan di Pelatihan Tourism and Home Assistant Program oleh Yayasan Aura Sukma Insani yang berlokasi di Banjar Dinas Babakan, Desa Sambangan, Kecamatan Sukasada, Kabupaten Buleleng, Indonesia. Penelitian dilakukan selama tiga bulan. Teknik pengumpulan data dilakukan dengan metode observasi, wawancara mendalam, dan studi dokumentasi. Teknik penentuan informan menggunakan teknik purposive sampling. Informan ditentukan berdasarkan pentingnya peran yang dijalankan di Tourism and Home Assistant Program dan keterlibatan secara langsung dalam kegiatan pemberdayaan tersebut. Informannya yaitu Ketua Yayasan Aura Sukma Insani, Direktur dan Koordinator Tourism and Home Assistant Program. Hasil penelitian dianalisis secara deskriptif kualitatif yang menyajikan keadaan objek sesuai dengan tujuan penelitian.

\section{Bentuk Pemberdayaan 'Tourism and Home Assistant Program'}

Berdasarkan hasil observasi dan hasil analisis data yang dilakukan, dapat dikemukakan bahwa ada dua jenis bentuk pemberdayaan yang dilakukan oleh Pelatihan Tourism and Home Assistant Program yaitu pelatihan pariwisata satu tahun dan pemberdayaan melalui bantuan insidental.

Pemberdayaan yang dilakukan oleh Tourism and Home Assistant Program melalui pelatihan pariwisata satu tahun adalah untuk menjamin peserta pelatihan dalam meningkatkan kemampuan, pengetahuan, dan sikap perilaku mereka sehingga mereka dapat bersaing di dalam mencari pekerjaan di industri pariwisata dan mereka dapat meningkatkan taraf hidup mereka. Proses pelatihan didukung oleh bantuan insidental yang merupakan usulan dari pengelola pelatihan kepada Yayasan Aura Sukma Insani untuk memperlancar proses pelatihan yang diikuti

Program ini merupakan bentuk pemberdayaan karena dengan pelatihan pariwisata satu tahun mampu mengubah peserta pelatihan dari kurang paham menjadi paham, dari kurang mampu menjadi mampu dan memiliki

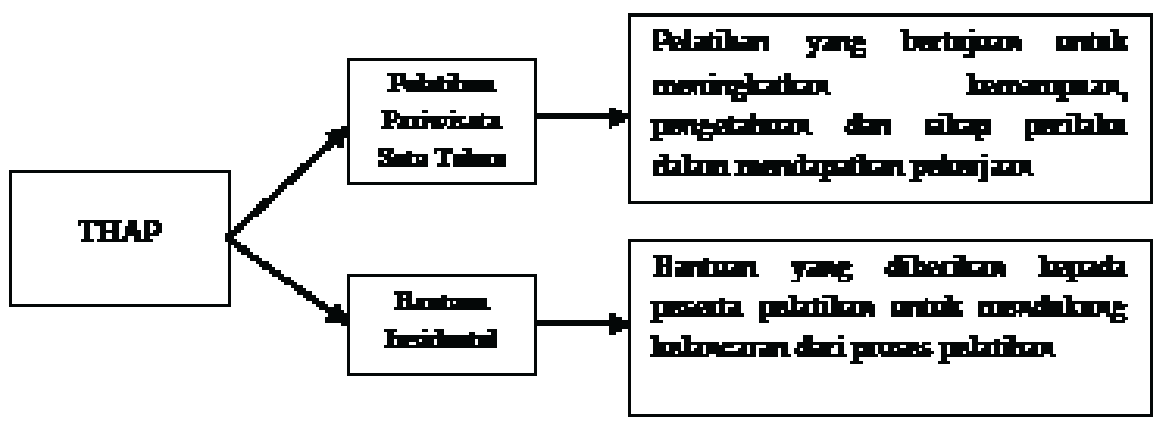

Gambar 1. Bentuk Pemberdayaan Pelatihan Tourism and Home Assistant Program 


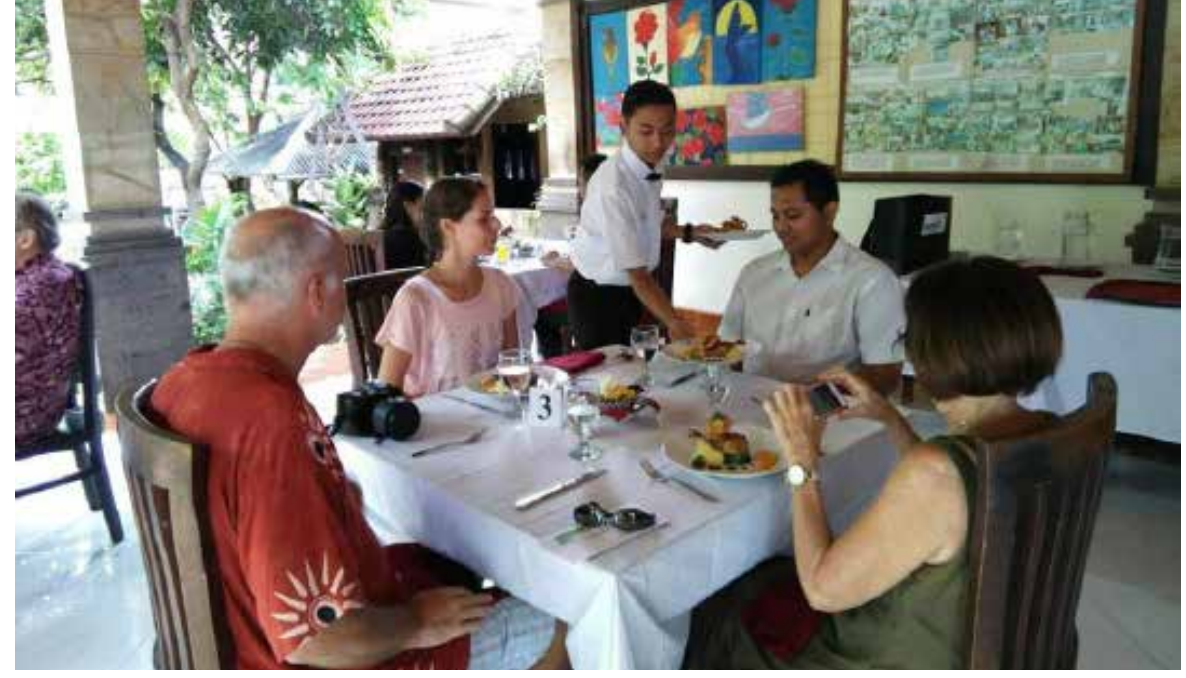

Foto 1. Salah satu praktik dalam kegiatan simulasi pelatihan di bidang tata hidang atau food and beverage service.

kompetensi. Dengan kata lain, pemberdayaan secara akademik yang memberi bekal kepada peserta pelatihan untuk bisa mendapatkan pekerjaan di industri.

Tujuan akhir pemberdayaan masyarakat adalah membuat masyarakat mandiri, berdaya, dan membangun kemampuan untuk memajukan diri ke arah kehidupan yang lebih baik secara bersinambungan (Kartasasmita, 1997). Dengan adanya Pelatihan Tourism and Home Assistant Program yang merekrut peserta dari desa terutama untuk mereka yang tidak mampu, pemberdayaan masyarakat untuk menjadi mandiri, berdaya dan membangun kemampuan untuk memajukan diri menjadi potensial, sangat mungkin untuk dicapai mengingat indikator kesuksesan lulusan Pelatihan Tourism and Home Assistant Program untuk bisa menuju pemberdayaan diri bisa diarahkan dan dicapai.

\section{Analisis Model Pemberdayaan Pelatihan 'Tourism and Home Assistant Program'}

Berdasarkan hasil wawancara dan analisis data tentang cara pembentukan model pemberdayaan pada Tourism and Home Assistant Program, terdapat delapan cara yaitu pembuatan kurikulum yang relevan, pengaturan manajemen, pemasaran, pengawasan, penggunaan sistem pelaksanaan pendidikan yang jelas, sistem perekrutan calon peserta pelatihan, kerja sama dengan pihak pemakai lulusan, dan memberikan professional development yang berkelanjutan.

Model pemberdayaan remaja kurang mampu melalui pelatihan Tourism and Home Assistant Program dibentuk oleh aspek-aspek terkait secara holistik dan terintegrasi. Pada model pemberdayaan ini, proses pelatihan dibagi menjadi proses internal dan eksternal.

Pada proses internal, Aspek yang pertama adalah sistem perekrutan calon peserta pelatihan. Pelatihan ini dibuat dengan tujuan untuk memberdayakan masyarakat yang kurang mampu. Jadi untuk menentukan 
peserta yang diberikan pelatihan harus tepat sasaran dan dilakukan dengan seleksi yang ketat. Aspek kedua adalah aspek kurikulum yang dilakukan dengan menekankan pada kurikulum berbasis multi-kompetensi dengan muatan lokal. Aspek ketiga yaitu menggunakan manajemen yang mencakup manajemen dalam bidang sumber daya manusia, waktu, dan kegiatan belajar mengajar. Aspek keempat adalah pengawasan. Pengawasan menjadi salah satu hal terpenting di dalam pencapaian tujuan dari pelatihan Tourism and Home Assistant Program. Pemberdayaan dalam hal pengawasan dilakukan dengan memberdayakan pengawasan secara berkelanjutan baik itu harian, mingguan dan bulanan. Aspek kelima adalah pemberdayaan dalam sistem pelaksanaan pelatihan yang mengimplementasikan sistem pelaksanaan pendidikan yang jelas. Dalam aspek ini semua komponen kurikulum baik itu perencanaan kurikulum dan pelaksanaannya harus dilaksanakan dengan baik agar tujuan pelatihan berhasil dan lulusan memiliki kompetensi sesuai dengan kebutuhan industri. Untuk menjamin mutu pendidikan, quality control yang berkelanjutan tetap dijaga dan dilaksanakan secara konsisten dan berkelanjutan. Aspek yang keenam adalah pemberian professional development yang berkelanjutan dengan bantuan relawan asing dan para lulusan yang sudah bekerja untuk memotivasi para peserta pelatihan.

Pada proses eksternal, Aspek pertama yaitu dari sisi pemasaran. Penyebaran informasi mengenai pelatihan dilakukan melalui penggunaan media sosial, bantuan pihak ketiga, dan relawan asing. Tujuan penyebaran informasi ini adalah untuk memberikan informasi terkini mengenai pemberdayaan melalui pelatihan Tourism and Home Assistant Program dan mengakomodasi jika ada sponsor yang ingin turut serta membantu dalam proses pelatihan seperti beasiswa dan bantuan insidental. Aspek kedua adalah kerja sama dengan pemakai lulusan. Kerja sama ini dilakukan untuk membantu pengelola program di dalam penyaluran peserta pelatihan di dalam mencarikan tempat training maupun tempat bekerja setelah mengikuti pelatihan. Kerjasama juga dimanifestasikan dalam bentuk pemberian narasumber oleh pihak hotel untuk menjadi instruktur tamu dalam pelatihan agar peserta memiliki keahlian sesuai dengan

Model pemberdayaan tersebut menyangkut pemberdayaan yang holistik karena menyangkut semua aspek yang berperan dalam memberdayakan peserta untuk memiliki keterampilan dan kompetensi yang memadai untuk bekerja di industri di lapangan. Model pemberdayaan juga dilakukan secara terintegrasi karena pemberdayaan dalam satu aspek mempengaruhi keberhasilan pada aspek yang lain. Misalnya dalam hal pengawasan yang dilakukan secara terus menerus menyebabkan pemberdayaan pada aspekaspek yang lain berjalan dengan baik sesuai dengan tujuan yang ingin dicapai. Dengan model pemberdayaan holistik dan terintegrasi ini, tujuan pelatihan untuk memberdayakan masyarakat (remaja) kurang mampu menjadi lebih 


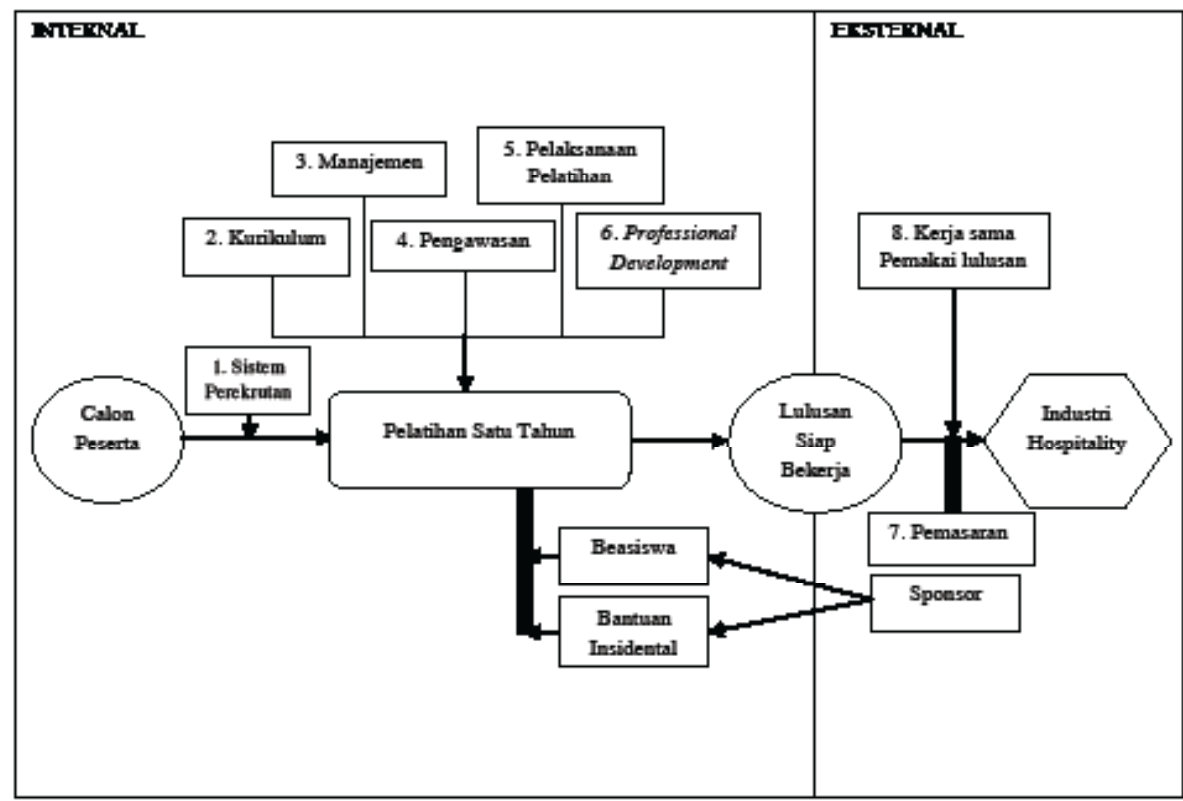

Gambar 2. Model Pemberdayaan Pelatihan Tourism and Home Assistant Program.

mudah untuk dicapai dan mereka merasakan dampaknya.

Dalam perspekif model pemberdayaan, pelatihan Tourism and Home Assistant Program jika dikaitkan dengan teori Rothman (1995) mengenai model pemberdayaan, pelatihan ini sendiri menerapkan kombinasi dari setiap model dari Rothman (1995) yaitu model pengembangan masyarakat lokal, model perencanaan sosial, dan model aksi sosial. Pada model pengembangan masyarakat lokal, model ini berorientasi pada proses dan memberikan perubahan dalam masyarakat dengan melibatkan partisipasi aktif masyarakat. Model pengembangan masyarakat lokal mencakup penggunaan prosedur yang tujuannya bersifat pendidikan. Dari pernyataan tersebut, pelatihan Tourism and Home Assistant Program meningkatkan partisipasi aktif masyarakat dan membantu meningkatkan kesadaran dan mengembangkan kemampuan masyarakat dalam mencapai tujuan-tujuan yang diharapkan dengan cara memberikan pengalaman belajar pada masyarakat, kepedulian dan kebanggaan sebagai anggota masyarakat.

\section{Manfaat 'Tourism and Home Assistant Program' terhadap Kegiatan Pariwisata di Kabupaten Buleleng}

Kegiatan pemberdayaan melalui pelatihan Tourism and Home Assistant Program memberi manfaat positif bagi masyarakat kurang mampu yang menjadi peserta kegiatan pemberdayaan tersebut yaitu, memperoleh skill tambahan dan digunakan untuk mencari pekerjaan. Selain bagi remaja kurang mampu, pelatihan Tourism and Home Assistant Program memberi manfaat bagi kegiatan pariwisata di Kabupaten Buleleng yaitu promosi 
kegiatan pariwisata Kabupaten Buleleng melalui kegiatan kepedulian sosial secara internasional.

Pariwisata di Buleleng menerima manfaat dari adanya Pelatihan Tourism and Home Assistant Program. Pelatihan ini memberikan dampak yang positif pada mulai berkembangnya pariwisata untuk tujuan melakukan kegiatan sosial di bidang kemanusiaan. Ada kecenderungan bahwa para wisatawan semakin banyak melakukan aktualisasi diri dengan melakukan aksi sosial membantu orang lain karena mereka menjadi orang yang sangat berguna dan bermanfaat bagi orang lain. Berkenaan dengan hal tersebut, para sponsor atau sukarelawan yang membantu jalannya program ini sering berkunjung ke Bali di samping untuk liburan juga untuk menengok keluarga asuh yang mereka bantu.

Selain para sponsor, Tourism and Home Assistant Program ini sering didatangi para relawan yang ingin membantu kegiatan pemberdayaan. Mereka berkontribusi dalam hal pengetahuan, kemampuan dan pemahaman budaya mengenai masyarakat di negara asalnya kepada peserta pelatihan untuk menambah wawasan tentang budaya asing sehingga lulusan Pelatihan Tourism and Home Assistant Program nantinya memiliki kesempatan dan peluang kerja lebih tinggi.

Selain itu, program Pelatihan Tourism and Home Assistant Program juga memberikan kesempatan kepada tamu atau sponsor untuk terlibat dalam pembelajaran di program Pelatihan Tourism and Home Assistant Program. Misalnya dalam mata kuliah Guiding. Program pelatihan ini memiliki pembelajaran Guiding, para peserta diberikan ilmu tentang cara menjelaskan daerah wisata. Pembelajaran tentang Guiding ini dilakukan dengan memberikan praktek langsung kepada peserta. Salah satu program Guiding yang diberikan di Pelatihan Tourism and Home Assistant Program adalah village tour, yaitu berupa perjalanan wisata untuk berkunjung ke desa tempat tinggal para peserta Pelatihan Tourism and Home Assistant Program. Untuk melaksanakan village tour ini, peserta Pelatihan Tourism and Home Assistant Program harus mampu merencanakan tour dibimbing oleh koordinator pelatihan. Peserta Pelatihan Tourism and Home Assistant Program harus mampu menjelaskan desanya termasuk memperkenalkan keluarga dan tempat tinggal mereka. Tentunya kemampuan ini memberikan nilai tambah untuk peserta jika sudah bekerja. Keterlibatan tamu sponsor adalah untuk menjadi tamu dalam program village tour tersebut.

Dengan kesempatan ini, para sponsor atau relawan dimintai tolong oleh peserta menjadi tamu yang diajak mendatangi desa tempat tinggal mereka. Mereka memainkan simulasi dan menjelaskan daya tarik wisata yang ada di Buleleng dekat tempat tinggal mereka. Selain daya tarik wisata, mereka diajak melihat rumah dan lingkungan tempat tinggal dari peserta. Mereka dikenalkan bagaimana kehidupan peserta dalam keseharian, misalnya 
bagaimana mereka tidur di rumah mereka, makan seadanya dengan peralatan seadanya, dan para sponsor atau relawan diajak ikut merasakan dan mengalami kesulitan hidup mereka (misalnya mencari rumput dan kayu api di tegalan, mencari air dengan berjalan kaki, bekerja di ladang atau di lumpur). Terkadang, para sponsor atau relawan menginap dan merasakan apa yang dirasakan oleh peserta pelatihan. Tentunya ini memberikan dampak pada tersimpannya memori khusus yang tidak terlupakan sepanjang hayat. Hal-hal sederhana ini ternyata memberi pengalaman yang luar biasa bagi para sponsor atau relawan dan menjadi potensi besar untuk memberdayakan kepedulian sosial para sponsor dan dapat menjadi suatu daya tarik tersendiri ke Kabupaten Buleleng.

Dengan kunjungan para sponsor ke Tourism and Home Assistant Program secara tidak langsung juga berimbas pada kunjungan wisatawan ke Buleleng. Pada Tabel 1 menunjukkan jumlah relawan atau sponsor yang berkunjung ke pelatihan Tourism and Home Assistant Program. Kunjungan sponsor dan relawan ke Tourism and Home Assistant Program pada Tabel 1 cenderung fluktuatif. Dari tahun 2010 sampai tahun 2012 mengalami kenaikan dari 110 sampai 190 orang berkunjung ke Tourism and Home Assistant Program. Tapi mengalami penurunan pada tahun 2013 yaitu 114 orang. Kunjungan terendah terjadi pada tahun 2015 yaitu sejumlah 80 orang dan meningkat dua kali lipat di tahun berikutnya sejumlah 170 orang. Dari sebelas negara yang sudah mengunjungi Tourism and Home Assistant Program, Australia yang paling banyak berkunjung ke Tourism and Home Assistant Program yaitu sejumlah 894 orang. Hal ini disebabkan karena sebagian besar para sponsor dan relawan berasal dari Australia.

Berdasarkan wawancara dengan Direktur Pelatihan, para relawan tinggal di Singaraja berkisar dari satu minggu sampai enam bulan. Para relawan biasanya tidur di kamar yang ada di Aura Sukma Insani Function Centre atau mereka memilih tinggal di hotel. Mereka biasanya mengisi kelas untuk mengajar di Pelatihan Tourism and Home Assistant Program dan setelah selesai kelas mereka kadang-kadang pergi mengelilingi daerah wisata yang ada di Buleleng. Sesekali para peserta pelatihan mengajak ke rumah mereka dan ke tempat wisata yang ada di rumah mereka.

Bagi pemerintah daerah, peningkatan kedatangan wisatawan ke daerah Buleleng berdampak pada popularitas wilayah secara nasional dan internasional yang secara langsung dapat meningkatkan pendapatan asli daerah (PAD) karena adanya peningkatan transaksi yang dilakukan selama berwisata di daerah Buleleng. Dengan semakin banyaknya para sponsor yang datang ke TourismandHome Assistant Program, akan otomatis meningkatkan tingkat kunjungan ke Kabupaten Buleleng. Hal ini akan membentuk suatu hubungan yang mutualisme. Tourism and Home Assistant Program bisa mengakomodasi keinginan para sponsor untuk mengunjungi dan melihat 
Tabel 1. Kunjungan Sponsor dan Relawan ke Tourism and Home Assistant Program

\begin{tabular}{llrrrrrrrr}
\hline \multirow{2}{*}{ No } & Negara Asal & \multicolumn{7}{c}{ Jumlah Kunjungan } & Total \\
\cline { 2 - 9 } & & 2010 & 2011 & 2012 & 2013 & 2014 & 2015 & 2016 & \\
\hline 1 & Amerika & - & 2 & - & - & - & - & - & 2 \\
2 & Australia & 100 & 150 & 174 & 110 & 140 & 74 & 146 & 894 \\
3 & Belanda & - & - & 2 & - & - & - & 4 & 6 \\
4 & Denmark & - & 2 & - & - & - & - & - & 2 \\
5 & Inggris & 4 & 2 & - & - & - & - & - & 6 \\
6 & Irlandia & 2 & - & - & - & - & - & - & 2 \\
7 & Jepang & - & - & 2 & - & - & - & - & 2 \\
8 & Jerman & - & 4 & 6 & - & - & - & - & 10 \\
9 & Kanada & 4 & 2 & 6 & 4 & 4 & 2 & 18 & 40 \\
10 & Selandia Baru & - & 2 & - & - & 2 & 2 & 2 & 8 \\
11 & Singapura & - & - & - & - & - & 2 & - & 2 \\
& Jumlah & 110 & 164 & 190 & 114 & 146 & 80 & 170 &
\end{tabular}

Sumber: Tourism and Home Assistant Program, 2016

langsung kegiatan pemberdayaan dan di sisi lain pemerintah terbantu dalam hal meningkatkan kunjungan wisatawan ke Kabupaten Buleleng.

Potensi ini sangat memungkinkan untuk dikembangkan karena menurut Kurniawati (2013) pariwisata berkelanjutan memiliki prinsip-prinsip antara lain partisipasi, keikutsertaan para pelaku (stakeholder), kepemilikan lokal, penggunaan sumber daya secara berkelanjutan, mewadahi tujuantujuan masyarakat, perhatian terhadap daya dukung, monitor dan evaluasi, akuntabilitas, pelatihan serta promosi. Dalam hubungannya dengan pariwisata Bali Utara, keikutsertaan masyarakat yang secara langsung bersedia terlibat dalam upaya memperkenalkan Bali Utara memberi kesempatan kepada mereka untuk meningkatkan pendapatan. Potensi ini perlu mendapat perhatian misalnya dengan memberikan perhatian lebih banyak dan lebih serius kepada lembaga-lembaga pelatihan seperti Pelatihan Tourism and Home Assistant Program agar pemuda-pemudi desa bisa dilatih dan diberdayakan untuk menjadi "pemain langsung" dalam bisnis pariwisata yang ada di desanya. Hal ini tentu tidak akan mudah, tetapi dengan keseriusan dan komitmen yang tinggi pemberdayaan ini secara perlahan akan membawa dampak yang lebih signifikan.

\section{Simpulan dan Saran}

Berdasarkan analisis hasil pembahasan, maka dapat ditarik simpulan sebagai berikut.

Bentuk-bentuk kegiatan pemberdayaan masyarakat kurang mampu Tourism and Home Assistant Program yaitu pelatihan pariwisata satu tahun dan pemberdayaan melalui bantuan insidental; analisis model pemberdayaan Tourism and Home Assistant Program adalah pembuatan kurikulum yang 


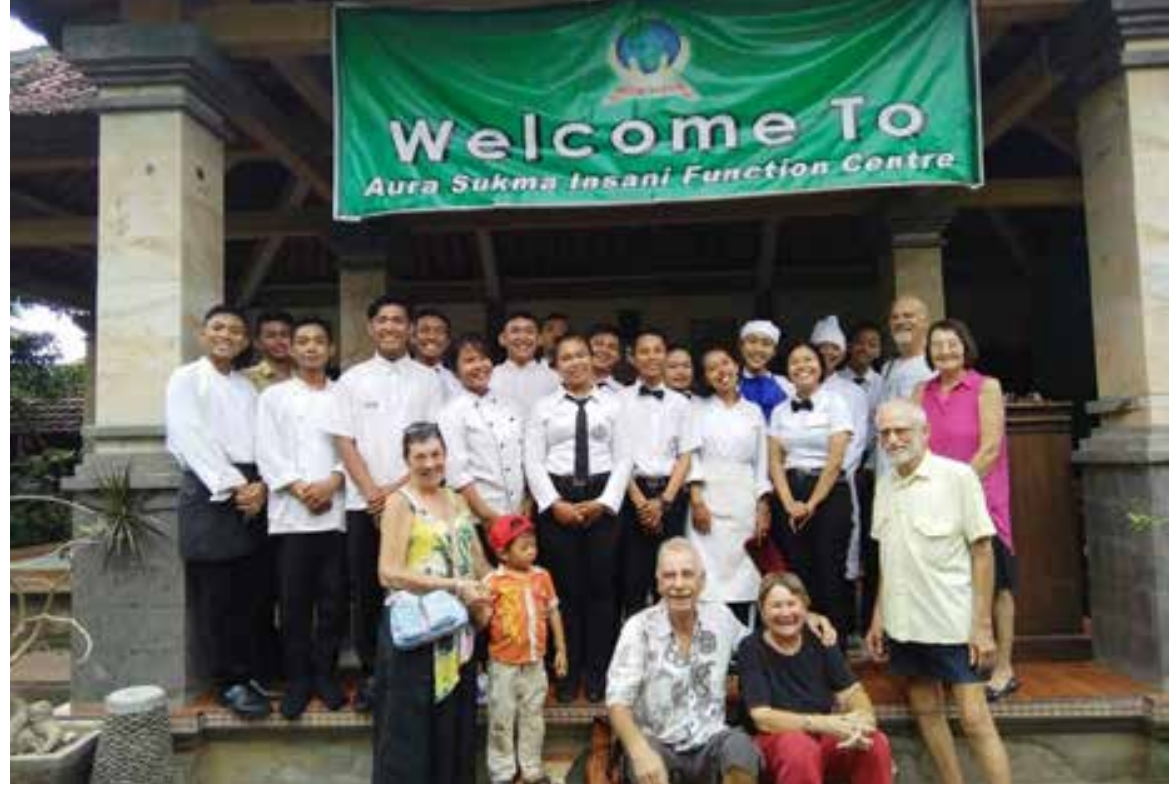

Foto 2. Setelah menyelesaikan pelatihan simulasi restaurant, kitchen dan front office para peserta pelatihan dan para tamu berkumpul untuk berfoto bersama.

relevan, pengaturan manajemen, pemasaran, pengawasan, penggunaan sistem pelaksanaan pendidikan yang jelas, sistem perekrutan calon peserta pelatihan, kerja sama dengan pihak pemakai lulusan, dan memberikan professional development yang berkelanjutan; manfaat Tourism and Home Assistant Program terhadap kegiatan wisata di Kabupaten Buleleng adalah promosi pariwisata Kabupaten Buleleng melalui kegiatan kepedulian sosial.

Berdasarkan bukti empiris yang diperoleh di lokasi penelitian dan perkembangan usaha pariwisata di Bali, maka dapat dikemukakan beberapa saran, antara lain. (1) Saran Kepada Pengelola Pelatihan Tourism and Home Assistant Program agar merekrut jumlah peserta yang lebih banyak setiap tahun, sehingga lebih banyak generasi muda yang bisa disiapkan untuk membangun pariwisata desa mereka maupun untuk berkecimpung di bidang pariwisata lainnya. (2) Promosi pariwisata Kabupaten Buleleng melalui kegiatan kepedulian sosial tepat untuk dikembangkan, oleh sebab itu pengelola Pelatihan Tourism and Home Assistant Program dipandang perlu untuk memberikan laporan/sosialisasi kepada pihak terkait agar program ini bisa dikembangkan. (3) Kepada pelaku pariwisata, pemberdayaan melalui Pelatihan Tourism and Home Assistant Program merupakan contoh program pemberdayaan masyarakat melalui bidang pariwisata yang bisa dipakai sebagai acuan.

\section{Ucapan Terimakasih}

Dalam penyusunan tesis ini penulis telah banyak mendapat bantuan dan dukungan serta motivasi dari berbagai pihak baik secara langsung maupun tidak langsung. Oleh karenanya pada kesempatan ini penulis mengucapkan terima kasih kepada Ni Made Sofia Wijaya, SST.Par.,M.Par.,Ph.D., dan Dr. Dewa Putu Oka Prasiasa, A.Par.,MM., selaku pembimbing I dan pembimbing 
II yang telah banyak memberikan bimbingan, petunjuk dan dorongan semangat dalam proses penulisan tesis ini. Kepada Prof. Dr. I Nyoman Darma Putra, M.Litt., yang telah senantiasa membantu penulis dalam memberikan bimbingan dan dukungan sehingga bisa menyelesaikan pendidikan pada Program Magister Kajian Pariwisata di Universitas Udayana Denpasar.

\section{Daftar Pustaka}

Adian, D. G. 2010. Pengantar Fenomenologi. Depok: Koekoesan.

Adiputra, I. P. M. 2013. "Pemberdayaan Masyarakat Miskin Di Hotel SulyResort, Yoga \& Spa melalui Yayasan Bali Global Ubud-Bali” (tesis).Denpasar: Universitas Udayana.

Arifin, Z. 2011. Evaluasi Pembelajaran Prinsip, Teknik, Prosedur. Bandung: PT Remaja Rosdakarya.

Arionesei, G., Vranciu, L. E., Neamtu, D. M., \& Morosan, A. A. 2014. "The Impact of Adult

Education And Training On Sustainable Development And Tourism In Suceava County", Revista De Turism-Studii Si Cercetari In Turism, (17). 42-48.

Bogdan, R. C., \& Biklen, S. K. 1982. Qualitative Research for Education: an introduction to theory and methods. London: Boston London.

Chan, J.K.L. 2011. "Enhancing the employability of and level of soft skills within tourism and hospitality graduates in Malaysia: The Issues and challenges", Journal of Tourism. Vol. XII, No. 1 2011, 1-16.

Dunham, A. 1958. The outlook for community development: An international symposium. School of Social Work, University of Michigan.

Fahrudin, A. 2011. Pemberdayaan Partisipasi \& Penguatan Kapasitas Masyarakat. Bandung: Humaniora.

Hatu, R. 2010. Pemberdayaan dan Pendampingan Sosial Masyarakat. Gorontalo: Jurnal Inovasi.

Kartasasmita, G. 1997. Pemberdayaan Masyarakat: Konsep Pembangunan yang Berakar pada Masyarakat. Yogyakarta: Universitas Gajah Mada.

López-Guzmán, T., Sánchez-Cañizares, S., \& Pavón, V. 2011. "Community-Based Tourism In Developing Countries: A Case Study”, Tourismos, An International Multidisciplinary Journal of Tourism, 6 (1), 69-84.

Manwa, H., Chipfuya, T., Mahachi, D. 2011. Tourism education in Botswana: A contested issue. Journal of Tourism. Vol. XII, No. 1 2011, 17-38.

Mardikanto, T., \& Soebianto, P. 2012. Pemberdayaan Masyarakat dalam Perspektif Kebijakan Publik. Bandung: CV Alfabeta.

Moleong, L. J. 2007. Metodologi Penelitian Kualitatif (Edisi Revisi). Bandung: PT. Remaja Rosdakarya.

Müller, F. 1997. "State-of-the-art in ecosystem theory”, Ecological modelling, 10o(1), 135-161.

Rothman, J. 1995. Approaches to Community Intervention.Diakses pada 4 Maret 
2017 dari http://gigihlardino.blogspot.co.id/2010/12/pengorganisasian-danpengembangan.html

Sharpley, R. 2000. Tourism and sustainable development: Exploring the theoretical divide. Journal of Sustainable tourism. 8(1). 1-19

Sugiyono. 2007. Metode Penelitian Kuantitatif Kualitatif dan R\&D. Bandung: Alfabeta.

Sugiyono. 2009. Metode Penelitian Pendidikan Pendekatan Kuantitatif, Kualitatif, dan R\&D. Bandung: Alfabeta

Suharto, E. 2005. Membangun Masyarakat Memberdayakan Rakyat. Bandung: PT. Refika Aditama.

Sulistyani, T. A. 2004. Kemitraan Dan Model-Model Pemberdayaan (Cetakan Pertama). Yogyakarta: Gaya Media.

Tukamushaba, E. K. 2011. Tourism training and education, Community empowerment and Participation in tourism planning and development. A case of Uganda. Journal of Tourism on Tourism Education, 12(1), 79.

\section{Profil Penulis}

I Gede Sukma Adisatria Sukadana adalah alumnus Program Studi Magister Kajian Pariwisata Fakultas Pariwisata Universitas Udayana Denpasar. Sebelumnya, menyelesaikan program studi Diploma IV, Administrasi Perhotelan di Sekolah Tinggi Pariwisata Nusa Dua Bali pada tahun 2012. Pada tahun 2015 melanjutkan program Magister di Universitas Udayana Denpasar dan tamat tahun 2017. Email: sukma.adisatria@gmail.com.

Ni Made Sofia Wijaya menamatkan pendidikan Diploma IV Pariwisata di Universitas Udayana Denpasar pada tahun 2003. Pada tahun 2007-2009, ia mengikuti Program Pascasarjana Universitas Udayana Denpasar. Di tahun 2007, ia mengikuti short course program International Degree Program in Tourism Management (ISTM) di University Applied of Sciences, Hochschule, Bremen. Menyelesaikan studi di Program Doktor Pariwisata Universitas Udayana Denpasar pada tahun 2015 dan kini menjadi salah satu dosen pengajar di Fakultas Pariwisata Universitas Udayana Denpasar. Email: mdsofiawij@gmail.com.

Dewa Putu Oka Prasiasa mengikuti kuliah di Program Diploma IV Pariwisata Universitas Udayana Denpasar dari tahun 1989 sampai tahun 1993. Menyelesaikan Program Magister Manajemen Sekolah Pascasarjana Universitas Sahid Jakarta pada tahun 1998 - 2000. Ia melanjutkan Program Doktor Kajian Budaya pada Program Pascasarjana Universitas Udayana Denpasar selama tiga setengah tahun dari 2006 - 2010. Pada tahun 2008, ia pernah mengikuti Program Sandwich di Faculty of Hospitaltity and Tourism Prince of Songkla University Phuket. Email: oka. dewaputu@yahoo.com. 